\title{
WSPARCIE KOBIET KARMIĄCYCH PIERSIĄ
}

\section{THE SUPPORT FOR BREAST-FEEDING MOTHERS}

\author{
Katarzyna Kanadys ${ }^{1}$, Dagmara Rzepecka ${ }^{2}$, Henryk Wiktor ${ }^{1,3}$ \\ ${ }^{1}$ Zakład Położnictwa, Ginekologii i Pielęgniarstwa Położniczo-Ginekologicznego \\ Uniwersytet Medyczny w Lublinie \\ ${ }^{2}$ Oddział Neonatologii, Patologii i Intensywnej Terapii Noworodka \\ Wojewódzki Szpital Specjalistyczny im. Stefana Kardynała Wyszyńskiego w Lublinie \\ ${ }^{3}$ Oddział Ginekologii i Położnictwa z Izbą Przyjęć \\ Wojewódzki Szpital Specjalistyczny im. Stefana Kardynała Wyszyńskiego w Lublinie
}

DOI: https://doi.org/10.20883/pielpol.2017.27

\section{STRESZCZENIE}

Wstęp. Okres połogu i związany z nim okres laktacji może łączyć się z wieloma trudnościami. W tym czasie kobiety potrzebują wsparcia ze strony swoich bliskich i personelu medycznego.

Cel pracy. Celem badań była ocena poziomu wsparcia kobiet karmiących piersią w zależności od czynników socjodemograficznych.

Materiał i metody. Badaniami objęto 200 położnic karmiących piersią, które były pacjentkami oddziału położniczo-noworodkowego Wojewódzkiego Szpitala Specjalistycznego im. Stefana Kardynała Wyszyńskiego w Lublinie. Badania przeprowadzono od listopada 2013 do lutego 2014 roku. Badania były dobrowolne i anonimowe. Badania przeprowadzono metodą sondażu diagnostycznego z wykorzystaniem narzędzia standaryzowanego Skali Wsparcia Społecznego autorstwa Krystyny Kmiecik-Baran, oraz kwestionariusza ankiety własnego autorstwa.

Wyniki. Na podstawie badań ustalono poziom ogólnego wsparcia społecznego otrzymywanego w badanej grupie kobiet karmiących. Przeprowadzone badania wykazały, że 51\% badanych kobiet otrzymywało średnie wsparcie społeczne, 45,5\% kobiet otrzymywało niskie wsparcie i tylko $3,5 \%$ badanych otrzymało wysoki poziom wsparcia.

Wnioski. Analiza uzyskanych wyników badań wykazała, że badane kobiety karmiące otrzymały średni poziom wsparcia społecznego. Ponadto badania wykazały, że stan cywilny badanych kobiet warunkował poziom wsparcia w okresie laktacji, który był wyższy w grupie kobiet pozostających w związku partnerskim niż będących mężatkami. Wiek, miejsce zamieszkania, wykształcenie oraz sytuacja materialna nie warunkowały poziomu wsparcia badanych położnic.

SŁOWA KLUCZOWE: karmienie piersią, wsparcie społeczne, czynniki społeczno-demograficzne.

\section{Wprowadzenie}

Karmienie naturalne to typowy sposób zachowania ssaków. Występuje u ludzi od początku istnienia gatunku. Do końca XIX wieku stanowiło jedyną metodę zapewnienia przeżycia i optymalnego rozwoju dziecka [1]. Natomiast na początku XX wieku na skutek gwałtownej

\section{ABSTRACT}

Introduction. Immediate postnatal and lactation period may cause many difficulties. During this time women need support of their relatives and medical personnel.

Aim. The aim of the paper was to assess the level of support given to the breast-feeding women depending on sociodemographic factors.

Matherial and methods. The survey included 200 breast-feeding women who had just had babies and were patients on the Materninty- Newborn Babies Ward at the Stefan Kardynał Wyszyński Voivodeship Specialist Hospital in Lublin. The survey was conducted from November 2013 to February 2014 and was voluntary and anonymous. It was conducted using a diagnostic poll with the standard instrument - Krystyna Kmiecik-Baran's Social Support Scale and the qustionnaire sheet prepared by the author.

Results. On the basis of the survey the level of general social support within the group of the breast-feeding women was established. It showed that $51 \%$ of the surveyed women received an average social support, $45.5 \%$ received low support and only $3.5 \%$ claimed to have recived high level of support.

Conclusions. the analysis of the results shows that women were given an average level of social support. Furthermore, the survey showed that marital status of the surveyed women conditioined the amount of suport received during the lactation period, thus the women being in partner relationships received more support than the married women. Age, place of birth, education and financial situation had no inluence on the level of suport offered to the women in the immediate postnatal period.

KEYWORDS: breast-feeding, social support, sociodemographic factors.

industrializacji i urbanizacji, zmian demograficznych, rozwoju nauki oraz wprowadzenia sztucznych mieszanek karmienie piersią zaczęło zanikać [2]. Obecnie ten negatywny proces został stopniowo zatrzymany dzięki działaniom wielu organizacji promujących karmienie piersią, takich jak WHO, UNICEF, Amerykańska Akade- 
mia Pediatrii czy Europejskie Towarzystwo Gastroenterologii, Hepatologii i Żywienia Dzieci (ESPGHAN) [3].

Okres połogu i związany z nim okres laktacji to trudny czas w życiu kobiety. W tym czasie potrzebuje ona wsparcia ze strony swoich bliskich, w szczególności od ojca dziecka [4]. Okres połogu to także nowa sytuacja, która niesie ze sobą lęk, niepokój, strach, dlatego bardzo istotne jest wsparcie, jakiego personel medyczny udziela położnicom [5].

Ostateczna decyzja o podjęciu bądź zaniechaniu karmienia należy do rodziców, a głównie do matki dziecka i jest uwarunkowana wieloma czynnikami emocjonalnymi, zdrowotnymi, społecznymi. Karmienie piersią jest możliwe, gdy matka wierzy we własne siły i ma pewność, że w obliczu trudności będzie w stanie sobie poradzić, natomiast w przypadku problemów będzie mogła uzyskać wsparcie [6].

W literaturze przedmiotu doniesienia wykazują, jak ważne dla zdrowia, zarówno fizycznego, jak i psychicznego, są więzy społeczne i wsparcie przez nie dostarczane [7-13]. W przystosowaniu do nowej sytuacji zdrowotnej i społecznej, w jakiej znalazła się kobieta karmiąca, istotną rolę odgrywa system wsparcia społecznego, który tworzą m.in. rodzina, przyjaciele oraz personel medyczny (lekarz, położna, pielęgniarka) [7].

Priorytetowym celem polityki zdrowotnej jest prawidłowe odżywianie noworodków i niemowląt, które wiąże się z efektywnym karmieniem piersią. Dlatego istotnym elementem pomocy medycznej jest wsparcie kobiety karmiącej piersią oraz stosowanie procedur, które popierają karmienie naturalne [14]. Grupa zawodowa położnych ma bardzo ważne zadanie. Dotyczy ono odpowiedzialności za promocję karmienia naturalnego w Polsce. Położne mają ogromny wpływ na początek i kontynuację karmienia piersią [15, 16].

\section{Cel pracy}

Celem pracy była ocena poziomu wsparcia kobiet karmiących piersią w zależności od czynników socjodemograficznych: wieku, stanu cywilnego, miejsca zamieszkania, wykształcenia, sytuacji materialnej.

\section{Materiał i metody badań}

Badaniami objęto 200 położnic karmiących piersią. Badane kobiety były pacjentkami oddziału położniczo-noworodkowego Wojewódzkiego Szpitala Specjalistycznego im. Stefana Kardynała Wyszyńskiego w Lublinie. Kryteria doboru do grupy badanej były dwa: karmienie piersią oraz pobyt dziecka z matką na jednej sali szpitalnej przez pierwsze doby połogu. Badania prowadzono od listopada 2013 do lutego 2014 roku. Badania były dobrowolne i anonimowe. Od badanych kobiet uzyska- no zgodę na udział w badaniu, po uprzednim wyjaśnieniu celu i przebiegu badań.

Projekt badania uzyskał pozytywną opinię Komisji Bioetycznej Uniwersytetu Medycznego w Lublinie (Nr KE-0254/288/2013).

Badania przeprowadzono metodą sondażu diagnostycznego z wykorzystaniem narzędzia standaryzowanego - Skali Wsparcia Społecznego autorstwa Krystyny Kmiecik-Baran [11], oraz kwestionariusza ankiety własnego autorstwa. Skala Wsparcia Społecznego Kmiecik-Baran służy do oceny wsparcia udzielanego przez cztery najbliższe ankietowanym kobietom grupy (mąż/ partner, rodzina, przyjaciele/znajomi, personel medyczny). Skala zawiera 16 twierdzeń, które są przeliczane na cztery rodzaje wsparć: informacyjne, instrumentalne, wartościujące, emocjonalne. Zadaniem osoby badanej jest określenie za pomocą czterostopniowej skali, w jakim stopniu dane twierdzenie odnosi się do wyodrębnionych grup społecznych (3 - tak, 2 - raczej tak, 1 - raczej nie, 0 - nie, nie dotyczy). Natomiast ankieta autorska dotyczyła danych socjodemograficznych badanych kobiet.

Badaniami objęto położnice w wieku od 19 do 43 lat. Średnia wieku badanych wynosiła 29,96 \pm 4,99 lat. Wśród badanych kobiet 36 (18,00\%), było w wieku do 25 lat, 83 (41,50\%), w wieku od 26 do 30 lat, 48 (24,00\%) w wieku od 31 do 35 lat i 33 (16,50\%) w wieku powyżej 35 lat. $175(87,5 \%)$ badanych kobiet to mężatki, natomiast 25 (12,5\%) badanych było w związku partnerskim. W badanej grupie 131 (65,5\%) kobiet mieszkało w mieście, natomiast 29 (34,5\%) badanych zamieszkiwała tereny wiejskie. 145 kobiet $(72,5 \%)$ posiadało wykształcenie wyższe, 46 (23\%) wykształcenie średnie, a 9 (4,5\%) wykształcenie poniżej średniego (podstawowe, gimnazjalne, zasadnicze zawodowe). 126 badanych (63\%) oceniło swoją sytuację materialną jako dobrą, natomiast 74 (37\%) jako średnią.

Uzyskane wyniki badań poddano analizie statystycznej. Do zbadania istnienia zależności między badanymi cechami użyto testu niezależności $\mathrm{Ch}^{2}$. Przyjęto poziom istotności $p<0,05$, wskazujący na istnienie istotnych statystycznie różnic bądź zależności. Bazę danych i badania statystyczne przeprowadzono w oparciu o oprogramowanie komputerowe STATISTICA 10.0 (StatSoft, Polska).

\section{Wyniki}

Na podstawie Skali Wsparcia Społecznego Krystyny Kmiecik-Baran ustalono poziom ogólnego wsparcia społecznego otrzymywanego w badanej grupie kobiet, który zilustrowano na rycinie 1. 

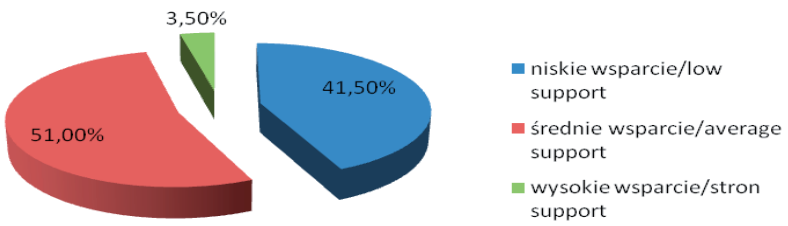

Rycina1. Poziom ogólnego wsparcia społecznego kobiet karmiących piersią Figure 1. Level of general social support of the breastfeeding women

Źródło: opracowanie własne

Source: author's own analysis

Przeprowadzone badania wykazały, że 51\% badanych kobiet otrzymywało średnie wsparcie społeczne, 45,5\% kobiet otrzymywało niskie wsparcie i tylko 3,5\% badanych otrzymało wysoki poziom wsparcia.

Analizę oceny wsparcia badanych kobiet w zależności od ich wieku przedstawiono w tabeli 1.

Tabela 1. Ocena poziomu wsparcia społecznego badanych kobiet, zależnie od ich wieku

Table 1. Assessing the level of social support concerning surveyed women depending on their age

\begin{tabular}{|c|c|c|c|}
\hline \multirow{3}{*}{ Wiek/Age } & \multicolumn{2}{|c|}{$\begin{array}{l}\text { Ocena wsparcia/ } \\
\text { Assessment of support }\end{array}$} & \multirow[b]{2}{*}{$\begin{array}{l}\text { Ogółem/ } \\
\text { Generally }\end{array}$} \\
\hline & Niskie/Low & $\begin{array}{l}\text { Średnie } \\
\text { i wysokie/ } \\
\text { Average } \\
\text { and strong }\end{array}$ & \\
\hline & n (\%) & $n(\%)$ & $n(\%)$ \\
\hline $\begin{array}{l}\text { Do } 25 \text { lat/ } \\
\text { up to } 25 \text { years }\end{array}$ & $13(36,11)$ & $23(63,89)$ & $36(100)$ \\
\hline $\begin{array}{l}26-30 \text { lat/ } \\
26-30 \text { years old }\end{array}$ & $41(49,9)$ & $42(50,6)$ & $83(100)$ \\
\hline $\begin{array}{l}31-35 \text { lat/ } \\
31-35 \text { years old }\end{array}$ & $21(43,75)$ & $27(56,25)$ & $48(100)$ \\
\hline $\begin{array}{l}\text { Powyżej } 35 \text { lat/ } \\
\text { over } 35 \text { years old }\end{array}$ & $16(48,48)$ & $17(51,52)$ & $33(100)$ \\
\hline \multicolumn{4}{|c|}{$\begin{array}{c}\text { Analiza statystyczna: } \mathrm{Chi}^{2}=1,97 ; \mathrm{p}=0,58 / \\
\text { Statistic analysis: } C h i^{2}=1,97 ; p=0,58\end{array}$} \\
\hline
\end{tabular}

Źródło: opracowanie własne

Source: author's own analysis

Na podstawie przeprowadzonej analizy statystycznej stwierdzono, że kobiety w wieku do 25 lat częściej otrzymywały średnie lub wysokie wsparcie społeczne niż badane w wieku 26-30 lat, 31-35 lat i powyżej 35 lat. Stwierdzone różnice nie były istotne statystycznie, $(p=0,58)$. Zatem badania własne wykazały, że wiek nie warunkował poziomu wsparcia kobiet, które karmiły piersią.

Analizę poziomu wsparcia społecznego kobiet karmiących w zależności od stanu cywilnego przedstawiono w tabeli 2.
Tabela 2. Ocena poziomu wsparcia społecznego kobiet karmiących, zależnie od ich stanu cywilnego

Table 2. Assessing the level of social support concerning surveyed women depending on their marital status

\begin{tabular}{|c|c|c|c|}
\hline \multirow{3}{*}{$\begin{array}{l}\text { Stan cywilny/ } \\
\text { Marital status }\end{array}$} & \multicolumn{2}{|c|}{$\begin{array}{c}\text { Ocena wsparcia/ } \\
\text { Assessment of support }\end{array}$} & \multirow[b]{2}{*}{$\begin{array}{l}\text { Ogółem/ } \\
\text { Generally }\end{array}$} \\
\hline & Niskie/Low & $\begin{array}{c}\text { Średnie i wysokie/ } \\
\text { Average } \\
\text { and strong }\end{array}$ & \\
\hline & $n(\%)$ & $n(\%)$ & $n(\%)$ \\
\hline Mężatka/Married & $85(48,57)$ & $90(51,43)$ & 175 (100) \\
\hline $\begin{array}{l}\text { Związek patnerski/ } \\
\text { In a relationship }\end{array}$ & 6 (24) & 19 (76) & $25(100)$ \\
\hline & $\begin{array}{l}\text { statystyczn } \\
\text { tic analysis. }\end{array}$ & $\begin{array}{l}C i^{2}=5,33 ; p=0,02^{*} / \\
h I^{2}=5,33 ; p=0,02^{*}\end{array}$ & \\
\hline
\end{tabular}

Źródło: opracowanie własne

Source: author's own analysis

Analiza statystyczna wykazała, że badane będące w związku partnerskim istotnie częściej $(p=0,02)$ uzyskiwały średnie lub wysokie wsparcie niż mężatki. Przeprowadzone badania własne wykazały, że stan cywilny badanych kobiet warunkował poziom wsparcia w okresie laktacji, który był wyższy w grupie kobiet pozostających w związku partnerskim niż będących mężatkami.

W tabeli 3 przedstawiono ocenę poziomu wsparcia społecznego matek karmiących zależnie od ich miejsca zamieszkania.

Tabela 3. Ocena poziomu wsparcia społecznego matek karmiących, zależnie od ich miejsca zamieszkania

Table 3. Assessing the level of social support of breastfeeding mothers depending on their place of living

\begin{tabular}{|c|c|c|c|}
\hline \multirow{3}{*}{$\begin{array}{c}\text { Miejsce } \\
\text { zamieszkania/ } \\
\text { Place of living }\end{array}$} & \multicolumn{2}{|c|}{$\begin{array}{c}\text { Ocena wsparcia/ } \\
\text { Assessment of suport }\end{array}$} & \multirow[b]{2}{*}{$\begin{array}{l}\text { Ogółem/ } \\
\text { Generally }\end{array}$} \\
\hline & Niskie/Low & $\begin{array}{l}\text { Średnie } \\
\text { i wysokie/ } \\
\text { Average } \\
\text { and strong }\end{array}$ & \\
\hline & $\mathrm{n}(\%)$ & $\mathrm{n}(\%)$ & $\mathrm{n}(\%)$ \\
\hline Miasto/City & $59(45,05)$ & $72(54,96)$ & $131(100)$ \\
\hline Wieś/Village & $32(46,38)$ & $37(53,62)$ & $69(100)$ \\
\hline Razem/Together & $91(45,5)$ & $109(54,5)$ & $200(100)$ \\
\hline \multicolumn{4}{|c|}{$\begin{array}{l}\text { Analiza statystyczna: } \mathrm{Chi}^{2}=0,03 ; p=0,86 \text { / } \\
\text { Statistic analysis: } \text { Chi }^{2}=0,03 ; p=0,86\end{array}$} \\
\hline
\end{tabular}

Źródło: opracowanie własne

Source: author's own analysis

Na podstawie przeprowadzonych badań własnych stwierdzono, że średnie lub wysokie wsparcie na zbliżonym poziomie otrzymywały badane mieszkające w mieście i na wsi. Zatem nie stwierdzono różnic istotnych statystycznie pomiędzy porównywanymi grupami. 
Analizę poziomu wsparcia społecznego badanych położnic w zależności od wykształcenia przedstawiono w tabeli 4.

Tabela 4. Ocena poziomu wsparcia społecznego badanych położnic, zależnie od ich wykształcenia

Table 4. Assessing the level of social support of breastfeeding mothers depending on their education

\begin{tabular}{|c|c|c|c|}
\hline \multirow[t]{2}{*}{$\begin{array}{l}\text { Wykształcenie/ } \\
\text { Education }\end{array}$} & $\begin{array}{r}\text { Ocena } \\
\text { Assessme }\end{array}$ & $\begin{array}{l}\text { parcia/ } \\
\text { of support } \\
\text { Średnie } \\
\text { i wysokie/ } \\
\text { Average } \\
\text { and strong }\end{array}$ & $\begin{array}{l}\text { Ogółem/ } \\
\text { Generally }\end{array}$ \\
\hline & $\mathrm{n}(\%)$ & $\mathrm{n}(\%)$ & $\mathrm{n}(\%)$ \\
\hline $\begin{array}{c}\text { Poniżej średniego/ } \\
\text { Lower than secondary } \\
\text { education }\end{array}$ & $5(55,56)$ & $4(44,44)$ & $9(100)$ \\
\hline $\begin{array}{c}\text { Średnie/ } \\
\text { Secondary education }\end{array}$ & $21(45,65)$ & $25(54,35)$ & $46(100)$ \\
\hline $\begin{array}{c}\text { Wyższe/ } \\
\text { Higher education }\end{array}$ & $65(44,83)$ & $80(55,17)$ & $145(100)$ \\
\hline $\begin{array}{r}\text { Analiza s } \\
\text { Statist }\end{array}$ & $\begin{array}{l}\text { tyczna: } \mathrm{Chi}^{2} \\
\text { alysis: } \mathrm{Chi}^{2}=\end{array}$ & $\begin{array}{l}39 ; p=0,82 \\
; p=0,82\end{array}$ & \\
\hline
\end{tabular}

Źródło: opracowanie własne

Source: author's own analysis

Badania własne wykazały, że kobiety z wykształceniem wyższym i średnim otrzymywały nieznacznie częściej średnie lub wysokie wsparcie w porównaniu z badanymi z wykształceniem niższym niż średnie. Stwierdzone różnice nie były znamienne statystycznie.

Analizę współzależności oceny poziomu wsparcia badanych kobiet i ich sytuacji materialnej przedstawiono w tabeli 5.

Tabela 5. Ocena poziomu wsparcia społecznego badanych kobiet, zależnie od ich sytuacji materialnej

Table 5. Assessing the level of social support of women depending on their financial situation

\begin{tabular}{|c|c|c|c|}
\hline \multirow{3}{*}{$\begin{array}{l}\text { Sytuacja materialna/ } \\
\text { Financial situation }\end{array}$} & \multicolumn{2}{|c|}{$\begin{array}{l}\text { Ocena wsparcia/ } \\
\text { Assessment of support }\end{array}$} & \multirow[b]{2}{*}{$\begin{array}{l}\text { Ogółem } \\
\text { Generall }\end{array}$} \\
\hline & Niskie/Low & $\begin{array}{l}\text { Średnie } \\
\text { i wysokie/ } \\
\text { Average } \\
\text { and strong }\end{array}$ & \\
\hline & $n(\%)$ & $n(\%)$ & $n(\%)$ \\
\hline Dobra/Good & $57(45,24)$ & $69(54,76)$ & $126(100)$ \\
\hline Średnia/Average & $34(45,95)$ & $40(54,05)$ & $74(100)$ \\
\hline \multicolumn{4}{|c|}{$\begin{array}{c}\text { Analiza statystyczna: } \mathrm{Chi}^{2}=0,01 ; \mathrm{p}=0,92 / \\
\text { Statistic analysis: } \mathrm{Chi}^{2}=0,01 ; p=0,92\end{array}$} \\
\hline
\end{tabular}

Źródło: opracowanie własne

Source: author's own analysis

Na podstawie przeprowadzonej analizy statystycznej stwierdzono, że kobiety z dobrą sytuacją materialną otrzymywały nieznacznie częściej średnie lub wysokie wsparcie w porównaniu z badanymi z przeciętną sytuacją materialną. Stwierdzone różnice nie były istotne statystycznie.

\section{Dyskusja}

Karmienie piersią to najlepszy sposób żywienia noworodków, niemowląt i małych dzieci. Zapewnia ono optymalny stan zdrowia i rozwój $[18,19]$. Karmienie naturalne zalecają światowe organizacje, takie jak WHO, UNICEF, AAP, ESPGHAN [12-15].

Wiele badań wykazało, że wsparcie społeczne pełni ważną rolę w zachowaniu zdrowia [7-13]. System wsparcia społecznego, tworzonego przez najbliższe otoczenie kobiety, jest również kluczowy dla matek karmiących piersią [7]. Okres połogu i związany z nim okres laktacji to trudny czas w życiu kobiety [4]. Wsparcie karmiącej ma duże znaczenie w zaakceptowaniu przez nią swojej roli społecznej, zwłaszcza kiedy dotyczy to pierwszego dziecka. Zdaniem Sztyber [25], wspierając karmiącą kobietę, pomagamy jej w budowaniu dobrej relacji z dzieckiem, która będzie procentowała w przyszłości. Matka karmiąca swoje dziecko piersią bardzo często pozostaje z nim w bezpośrednim kontakcie. Dzięki temu lepiej zna i rozumie swoje dziecko, ma więcej możliwości cieszenia się jego bliskością, częściej doświadcza poczucia spełnienia w macierzyństwie.

W literaturze przedmiotu istnieją doniesienia $[4,5$, 24, 25], w których podkreślono, jak ważną rolę odgrywa wsparcie matki karmiącej, jednakże niewielu badaczy określa poziom wsparcia społecznego otrzymywanego przez te kobiety. Natomiast w badaniach własnych podjęto próbę oceny poziomu wsparcia społecznego kobiet karmiących piersią. Badania własne wykazały, że ogólny poziom wsparcia społecznego otrzymywanego w badanej grupie kobiet był średni, 45,5\% kobiet otrzymywało niskie wsparcie i tylko 3,5\% badanych otrzymało wysoki poziom wsparcia.

W badaniach własnych podjęto również próbę oceny poziomu wsparcia społecznego kobiet karmiących zależnie od zmiennych socjodemograficznych charakteryzujących badaną grupę kobiet, takich jak: wiek, stan cywilny, miejsce zamieszkania, wykształcenie, sytuacja materialna.

Badania własne wykazały, że poziom wsparcia społecznego kobiet karmiących nie był uwarunkowany wiekiem badanych. W analizowanym piśmiennictwie nie znaleziono doniesień dotyczących współzależności między wiekiem kobiet karmiących piersią a otrzymywanym wsparciem społecznym. Jedynie Łepecka-Klusek i wsp. [26] wykazali zależność pomiędzy wiekiem a potrzebą wsparcia psychicznego w grupie kobiet przed operacją ginekologiczną. Cytowani autorzy wy- 
kazali, iż kobiety starsze w porównaniu z młodszymi oczekują wsparcia przeważnie od personelu medycznego. Natomiast rzadziej mogły liczyć na wsparcie ze strony rodziny.

Badania Zielińskiej-Więczkowskiej i Betłakowskiego [27] wykazały, że w grupie badanych hospitalizowanych poddanych chemioterapii na etapie diagnozy stan cywilny istotnie wyznaczał poziom wsparcia społecznego. Najwyższe wsparcie społeczne otrzymywały osoby pozostające w związku małżeńskim lub partnerskim, natomiast najniższe osoby rozwiedzione i owdowiałe. W kolejnych badaniach Zielińskiej-Więczkowskiej i wsp. [28] stwierdzono, że badani w podeszłym wieku którzy pozostawali w związku małżeńskim wyżej oceniali poziom wsparcia przed zabiegiem operacyjnym, niż osoby samotne. Ponadto badania Głębockiej i Szarzyńskiej [29] w grupie osób starszych wykazały, że osoby pozostające w związkach otrzymywały istotnie wyższy poziom wsparcia aniżeli osoby samotne. Stringhini i wsp. [10] stwierdzili, iż wsparcie społeczne, a szczególnie wielkość sieci i uregulowany stan cywilny warunkowały poprawę stanu zdrowia i zmniejszenie śmiertelności. Natomiast w przeprowadzonych badaniach własnych wykazano istotną statystycznie współzależność pomiędzy poziomem wsparcia kobiet karmiących a stanem cywilnym. Badania wykazały, że badane będące w związku partnerskim istotnie częściej uzyskiwały średnie lub wysokie wsparcie niż mężatki. Zatem stan cywilny warunkował poziom wsparcia społecznego w badanej grupie kobiet.

W badaniach własnych wykazano, że poziom wsparcia społecznego nie zależał od miejsca zamieszkania. Zatem miejsce zamieszkania nie różnicowało poziomu uzyskiwanego wsparcia społecznego w badanej grupie kobiet. Podobne wyniki uzyskały Kurowska i Kowalczyk [30] w badaniach grupy osób z rozpoznaniem raka jajnika i jądra. Natomiast badania Zielińskiej-Więczkowskiej i wsp. [28] wykazały, że miejsce zamieszkania ma wpływ na otrzymywany poziom wsparcia społecznego. Cytowani autorzy wykazali, że większym wsparciem cieszyli się mieszkańcy miasta niż wsi.

Badania własne wykazały, że wykształcenie nie warunkowało poziomu uzyskiwanego wsparcia społecznego w badanej grupie położnic. Podobne wyniki uzyskały Kurowska i Kowalczyk [30] w grupie osób z rozpoznaniem raka jajnika i jądra. Natomiast badania Zielińskiej-Więczkowskiej i wsp. [28] wykazały, że wykształcenie różnicuje poziom otrzymywanego wsparcia społecznego. Pacjenci w podeszłym wieku, posiadający wykształcenie średnie deklarowali najwyższy poziom wsparcia społecznego przed zabiegiem operacyjnym, natomiast pacjenci z wykształceniem podstawowym uzyskali najniższy poziom tego wsparcia.
Badania Zielińskiej-Więczkowskiej i Betłakowskiego [27] oraz Zielińskiej-Więczkowskiej i wsp. [28] wykazały, że sytuacja materialna była czynnikiem istotnie różnicującym poziom otrzymywanego wsparcia społecznego. Wyższy poziom wsparcia społecznego korelował z dobrą sytuacją materialną, natomiast niższy poziom wsparcia $z$ trudną sytuacją finansową. Ponadto badania przeprowadzone przez Gorman i Sivaganesan [13] w grupie dorosłych z nadciśnieniem tętniczym dowiodły, że szczególnego wsparcia potrzebują osoby z wykształceniem niższym niż średnie, będące w trudnej sytuacji finansowej oraz niepracujące zawodowo. Natomiast przeprowadzone badania własne nie wykazały istotnych statystycznie różnic pomiędzy poziomem wsparcia społecznego kobiet karmiących a sytuacją materialną. Zatem sytuacja materialna nie warunkowała poziomu wsparcia społecznego w badanej grupie kobiet.

Reasumując wyniki analizy poziomu wsparcia badanych kobiet karmiących piersią zależnie od czynników socjodemograficznych należy stwierdzić, że jedynie stan cywilny był czynnikiem warunkującym wsparcie. Natomiast wiek, wykształcenie, sytuacja materialna i miejsce zamieszkania nie różnicowały badanej grupy kobiet.

\section{Wnioski}

1. Badane kobiety karmiące otrzymały średni poziom wsparcia społecznego.

2. Stan cywilny badanych kobiet warunkował poziom wsparcia w okresie laktacji, który był wyższy w grupie kobiet pozostających w związku partnerskim niż będących mężatkami.

3. Wiek, miejsce zamieszkania, wykształcenie oraz sytuacja materialna nie warunkowały poziomu wsparcia badanych położnic.

\section{Piśmiennictwo}

1. Gebuza G, Gierszewska M, Kaźmierczak M, Michalska E, Kotzbach R. Przygotowanie kobiet do karmienia piersią. Probl Pielęg 2010; 18(4): 406-412.

2. Silska S. Ewolucja poglądów na żywienie niemowląt w XIX i XX wieku. Praca doktorska. Poznań: Uniwersytet Medyczny im. Karola Marcinkowskiego w Poznaniu; 2013.

3. Nehring-Gugulska M, Sztyber B, Pietkiewicz A. Promocja karmienia piersią. W: Nehring-Gugulska M, Żukowska-Rubik M, Pietkiewicz A. (red.) Karmienie piersią w teorii i praktyce. Med Prakt 2012. 31-39.

4. Doroszewska A. Rola współczesnego ojca w opiece nad noworodkiem i jego matką. Położ. Nauka Prakt. 2012; 1(17): 30-33.

5. Makara-Studzińska M, Wdowiak A, Podstawka D, Stec M. Opieka personelu medycznego oddziałów położniczych nad kobietą i noworodków w ocenie pacjentek. Med. Og. Nauk Zdr. 2013; 19 (3): 288-293.

6. Pietkiewicz A. Problemy psychologiczne w okresie okołoporodowym. W: Nehring-Gugulska M, Żukowska-Rubik M, 
Pietkiewicz A.(red.) Karmienie piersią w teorii i praktyce. Med Prakt 2012. 303-309.

7. Lelonek B, Kamusińska E. Analiza dostępu wsparcia społecznego u pacjentów oddziału chirurgicznego. Stud. Med. $2011 ; 23(3): 35-42$.

8. Tobiasz-Adamczyk B. Wybrane elementy socjologii zdrowia i choroby. Wyd. 2. Kraków: Wyd. UJ; 2000.

9. Kroenke CH, Quesenberry C, Kwan ML, Sweeney C, Castillo A, Caan BJ. Social networks, social support, and burden in relationships, and mortality after breast cancer diagnosis in the Life After Breast Cancer Epidemiology (LACE) study. Breast Cancer Res Treat. 2013 Jan;137(1):261-71.

10. Stringhini S, Berkman L, Dugravot A et al. Socioeconomic status, structural and functional measures of social support, and mortality. The British Whitehall II Cohort Study, 19852009. American Am J Epidemiol. 2012; 175 (12): 1275-1283.

11. Sinokki M, Hinkka K, Ahola K, et al. The association of social support at work and in private life with mental health and 2009;115(1-2):36-45.

12. Holt-Lunstad J, Birmingham W, Jones BQ. Is there something unique about marrige? The relative impact of marital status, relationship quality, and network social support on ambulatory blood pressure and mental health. Annals Behav. Med. 2008, 35: 239-244.

13. Gorman BK, Sivaganesan A. The role of social support and integration for understanding socioeconomic disparities in self-rated health and hypertension. Soc Sci Med. 2007; 65 (5): 958-975

14. Sztyber B, Dmoch-Gajzlerska E. Formy pomocy matkom z problemami laktacyjnymi. Położ. Nauka Prakt. 2008; 2 : 52-59.

15. Sztyber B. Nauka karmienia piersią - ważna rola położnej. Położ. Nauka Prakt. 2010; wyd. spec.: 6-11.

16. Sztyber B, Dmoch-Gajzlerska E. Profesjonalna pomoc laktacyjna. Położ. Nauka Prakt. 2008; 4: 55-58.

17. Kmiecik-Baran K. Narzędzia do rozpoznawania zagrożeń społecznych w szkole. Podręcznik. Wyd. 1. Gdańsk: Wyd. Przegląd Oświatowy; 2000.

18. Chmielewska D, Sztyber B. Karmienie dzieci po cięciu cesarskim. Położ. Nauka Prakt. 2010; 3(11): 44-50.

19. Wąs. B, Płoch K. Działalność poradni laktacyjnej w świadomości matek karmiących. Położ. Nauka i Prakt. 2011; 2(14): 40-45.

20. Całka K, Sztyber B. Czynniki wpływające na sposób żywienia wcześniaków $w$ ciągu pierwszych sześciu miesięcy życia. Położ. Nauka Prakt. 2013; 2(22): 52-56.

21. Durka A, Dmoch-Gajzlerska E. Żywienie zdrowych noworodków i niemowląt. Położ. Nauka Prakt. 2012; 2(18): 50-52.
22. Królak-Olejnik B, Nehring-Gugulska B, Osliso A. Standard potęgowania poporodowego sprzyjający karmieniu naturalnemu noworodków z małą urodzeniową masą ciała. Stand. Med. Pediatr. 2012; 9(3): 405-411.

23. Książyk J, Friedman-Gruszczyńska J, Laskowska J, Sibilska M, Świetliński J, Migdał M. i wsp. Żywienie zdrowych noworodków i niemowląt w pierwszym półroczu życia. Post. Neonatol. 2007; 2: 37-42.

24. Frąc $D$, Nestorowicz A, Skurzak A. Wsparcie w okresie laktacji. Pielęg. Położ. 2001; 43(7): 18-20.

25. http://www.kobiety.med.pl/cnol/index.php?option=com content\&view $=$ article\&id=178\%3A34-wspieranie-kobietkarmicych-piersi (dostęp z dnia 22.06.2016).

26. Łepecka-Klusek C, Pilewska-Kozak A, Syty K, Jakiel G. Potrzeba wsparcia psychicznego kobiet w okresie oczekiwania na operację ginekologiczną. Prz. Menopauz. 2010; 9(5): 309-314.

27. Zielińska-Więczkowska H, Betłakowski J. Pomiar i ocena wsparcia społecznego u pacjentów hospitalizowanych poddanych chemioterapii. Współ. Onkol. 2010; 14(3): 229-232.

28. Zielińska-Więczkowska H, Pryka K, Muszalik M, KędzioraKornatowska K. Wsparcie w opiece pielęgniarskiej pacjentów w podeszłym wieku przed zabiegiem operacyjnym - na tle czynników socjo-demograficznych. Psychogeriatr. Pol. 2012; 9(2): 61-68.

29. Głębocka A, Szarzyńska M. Wsparcie społeczne a jakość życia ludzi starszych. Gerontol. Pol. 2005; 13(4): 255-259.

30. Kurowska K, Kowalczyk E. Poczucie koherencji a wsparcie społeczne u osób z rozpoznanym rakiem jajnika i jądra. Probl. Pielęg. 2011; 19(3): 329-334.

Artykuł przyjęty do redakcji: 14.03.2016

Artykuł przyjęty do publikacji: 20.07.2016

Źródło finansowania: Praca nie jest finansowana z żadnego źródła. Konflikt interesów: Autorzy deklarują brak konfliktu interesów.

Adres do korespondencji:
Katarzyna Kanadys
ul. Chodźki 6
20-093 Lublin
tel.: 814486930
e-mail: kanadysk@wp.pl
Zakład Położnictwa, Ginekologii i Pielęgniarstwa Położniczo-Gi-
nekologicznego
Uniwersytet Medyczny w Lublinie

